\title{
Ivóvízminták mikrobiológiai és kémiai vizsgálata a Pannon-Víz Zrt. működési területén
}

\section{Microbiological and chemical investigation of drinking water samples on the operational area of Pannon Víz} Zrt.

\author{
Zs. KovÁCS ${ }^{1}$, R. MISETA², A. ZSENI ${ }^{3}$ \\ 15zéchenyi István Egyetem, Audi Hungaria Járműmérnöki Kar, Környezetmérnöki Tanszék, környezetmérnök \\ hallgató, kovacszsofia@outlook.com \\ 2Pannon-Víz Zrt., Minőségvizsgáló Laboratórium, miseta.roland@pannon-viz.hu \\ 33Széchenyi István Egyetem, Audi Hungaria Járműmérnöki Kar, Környezetmérnöki Tanszék, zseniani@sze.hu
}

\begin{abstract}
Absztrakt. Tanulmányunkban a Pannon-Víz Zrt. müködési területén 2015. január 1. - 2017. október 31. közötti időszakban követtük nyomon az ivóvízminőség változását. A környezeti hőmérséklet változása, a mikrobiológiai terheltség és az egyes kémiai paraméterek értékei között kerestünk összefüggést. Az adatok kiértékelését követően az alábbiakat állapítottuk meg. A mikrobiológiai pozitív minták szezonális változásait az Escherichia coli és Enterococcus baktériumok, illetve a Pseudomonas aeruginosa szennyezettség alapján lehetett meghatározni. A coliform baktériumcsoport és a $22^{\circ} \mathrm{C}$-os, $37^{\circ} \mathrm{C}$-os telepszám megjelenése nem mutatott szezonális dinamikát. Az elemzett kémiai paraméterek a vizsgált időszakban mindig határérték alatt maradtak. A kémiai és a mikrobiológiai paraméterek közötti összefüggés feltárására alkalmazott korreláció analízis alapján a vizsgált paraméterek között nem adható meg kapcsolat.
\end{abstract}

Abstract. In our research the potable water quality was monitored between 1 January 2015 and 31 October 2017 in the operational area of Pannon-Víz Zrt. The connection between temperature, microbiological load and chemical parameters were investigated. After evaluating data, the following results have been identified. The seasonal changes of the microbiologically positive samples are determined by the contamination caused by Escherichia coli, Enterococci and Pseudomonas aeruginosa. The coliform group and the $22^{\circ} \mathrm{C}$ and $37^{\circ} \mathrm{C}$ colony-form units showed no seasonal dynamics. The analysed chemical parameters were below the limit during the examined period. Based on the correlation analysis, there is no correlation between chemical and microbiological parameters.

\section{Bevezetés}

Az ivóvízhálózatba került tisztított ivóvízben a mikrobiológiai és kémiai folyamatok lejátszódása minőségromlást okozhat. A korróziós és a mikrobiológiai folyamatok hatnak egymásra. A vízfogyasztás csökkenése, a csőben való tartózkodási idő növekedése, a maradék fertőtlenítőszer elfogyása mikrobiológiai korrózióhoz vezet, az ivóvízhálózatban különféle vírusok, baktériumok, protozoák 
jelenhetnek meg [1]. A vízzel érintkező felületeken a megfelelő mennyiségű tápanyag és nedvesség lehetővé teszi a biofilm kialakítását, amely élettérként szolgál a mikroorganizmusok és a magasabb rendű szervezetek számára [2]. A biofilm a víz mellett baktériumsejteket, polimer anyagokat, tápanyagokat, anyagcseretermékeket, szemcsés anyagokat tartalmaz [3, 4]. Nem stabil szervezetek, ezért állandó változás, folyamatos megkötődés, leválás, szaporodás, elhalás jellemzi őket [5]. A biofilm mikrobaközösségének összetétele és dinamikája számtalan tényezőtől függ, mint például a cső anyaga [6], a hőmérséklet, a vízhálózat átöblítésének gyakorisága, a különféle fémek és a foszfát jelenléte stb. A biofilm eltávolításának lehetőségeivel kapcsolatos vélemények megoszlanak. A kutatások egy része arra a megállapításra jutott, hogy a poliszacharid réteg a fertőtlenítőszerrel reakcióba lép, így elfogy, mielőtt az élő szervezetek közelébe jutna. Más kutatások alapján a biofilmben élő baktériumok ellenállóbbak a fertőtlenítőszerekkel és az egyéb külső hatásokkal szemben, ezért ez az eljárás nem gátolja hatékonyan a mikroorganizmusok szaporodását [7, 8]. A csőrendszer átöblítése gyakran alkalmazott tisztítási módszer $[9,10]$, azonban az öblítés nem képes a csövekhez kapcsolódó biofilmet teljes mértékben eltávolítani, és a baktériumok a fennmaradó anyagból tovább szaporodhatnak [11].

Tanulmányunkban a Pannon-Víz Zrt. múködési területén 2015. január 1. - 2017. október 31. közötti időszakban gyűjtött ivóvízminták mikrobiológiai minőségét elemezzük. Kutatásunk során kiindulási feltevésünk az volt, hogy az egyes minták mikrobiológiai összetételében a szezonális változás nyomon követhető. A budapesti ivóvízhálózat baktériumközösségének térbeli és időbeli változását nyomon követő korábbi vizsgálat során a közösség összetételének változását vizsgálták a Szentendrei kutaktól a fogyasztói pontokig [12]. A kutatás megállapította, hogy a hőmérséklet jelentősen befolyásolta a Szentendrei-szigetről származó és a fővárosi minták baktériumközösségének összetételét, annak ellenére, hogy azok lényegesen különböztek egymástól.

Feltételezésünk szerint az egyes mintavételi pontokról gyűjtött minták vízminősége a környezeti, illetve a hálózati vízhőmérséklet emelkedésével romlik, a levegő és a hálózati víz lehűlésével pedig javul, azaz a vízminőség szezonális változást mutat. A minták szezonális eloszlásának értékeléséhez a normalizált telepszámokat és a hőmérsékleti adatokat vetettük össze. Feltételeztük azt is, hogy az egyes kémiai paraméterek koncentrációja és a vízminta mikrobiológiai terhelése között összefüggés van. Az összefüggést korreláció analízis segítségével vizsgáltuk.

\section{Anyag és módszer}

Munkánk során a 2015. január 1. és 2017. október 31. közötti hálózati ivóvízmintákat (kimenő hálózati víz, közkifolyó, fogyasztói mintavételi pont) dolgoztuk fel a Pannon-Víz Zrt. Minőségvizsgáló Laboratóriumában. A minták a Pannon-Víz Zrt. működési területéről származnak, 134 településről. A győri üzemmérnökséghez 26 , a nyúli üzemmérnökséghez 43 , a csornai üzemmérnökséghez 44, míg a kapuvári üzemmérnökséghez 21 település tartozik.

A győri üzemmérnökség területén a szigetközi kavicsos vízadó rétegekből parti szűrésű kutakkal történik a víz kitermelése a Révfalui és a Szőgyei Vízműben, a vízkezelés során vas- és mangántalanítás történik. A másik három vízellátó rendszer rétegvízre települt, a vízbeszerzés fiatal kavicsos, homok képződményekből, vagy a felső pannon homokrétegekből történik. E rétegekből termelt víz minősége 
védettségük miatt általában jó, azonban magas vas- és mangántartalmuk miatt helyenként kezelést igényelnek. Rendszeres hálózati vízfertőtlenítésre a vizsgálatba vont területen nincs szükség.

A vízmintavétel az MSZ EN ISO 19458:2007 szabvány szerint történt a Pannon-Víz Zrt. munkatársai által. A mintavételi csap 4-5 percig való folyatását követően a csaptelep szájának sterilizálása szúrólánggal történt, majd 0,5 literes steril üvegpalackokba kerültek a vízminták. A helyszínen került sor a minták vízhőmérsékletének mérésére. A laboratóriumba hűtve szállított mintákat a feldolgozásig 4-8 $\mathrm{C}$-on tároltuk. A vízminták feldolgozását 24 órán belül megkezdtük.

A vizsgálatokat a Pannon-Víz Zrt. akkreditált Minőségvizsgáló Laboratóriumában európai és magyar szabványok alapján végeztük el. A vizsgálatba vont paramétereket, azok vizsgálati módszereit és a mérés alapját az 1. táblázatban összegeztük.

\begin{tabular}{|l|l|l|}
\hline \multicolumn{1}{|c|}{ mért paraméter } & \multicolumn{1}{c|}{ vizsgálati módszer } & \multicolumn{1}{c|}{ a mérés alapja } \\
\hline Telepszám $20^{\circ} \mathrm{C}$-on és $37^{\circ} \mathrm{C}$-on & MSZ EN ISO 6222:2000 & lemezöntéses módszer \\
\hline Escherichia coli és coliform baktériumok & MSZ EN ISO 9308-1:2015 & membránszűrés \\
\hline Enterococcus baktériumok & MSZ EN ISO 7899-2:2000 & membránszűrés \\
\hline Pseudomonas aeruginosa & MSZ EN ISO 16266:2008 & membránszűrés \\
\hline Clostridium perfringens & MSZ EN ISO 14189:2017 & membránszürés \\
\hline Kémiai oxigénigény (KOI $\left.{ }_{\mathrm{ps}}\right)$ & MSZ 448-20:1990 & oxidációt követő titrálás \\
\hline Ammónium $\left(\mathrm{NH}_{4}{ }^{+}\right)$ & MSZ ISO 7150-1:1992 & fotometria \\
\hline Nitrit $\left(\mathrm{NO}_{2}{ }^{-}\right.$) és nitrát $\left(\mathrm{NO}_{3}{ }^{-}\right)$ & MSZ 1484-13:2009 & spektrofotometria \\
\hline
\end{tabular}

1. táblázat: Az ivóvízminták analitikai vizsgálata során meghatározott paraméterek és azok vizsgálati módszere.

A minták pozitivitásának megítélése az ivóvíz minőségi követelményeiről és az ellenőrzés rendjéről szóló 201/2001. (X.25.) kormányrendeletben megadott határértékek szerint történt. A pozitív mikrobiológiai jellemzők eloszlását a hálózati vízhőmérséklet függvényében követtük nyomon. A vizsgálathoz a telepszámokat normalizáltuk. A normalizálás során az adatok 0-1 közötti intervallumba kerültek. Az adatbázis normalizálását az alábbi módon végeztük:

Normál $\left(\mathrm{e}_{\mathrm{i}}\right)=\frac{e i-E \min }{E \max -E \min }$

ahol:

$e_{\mathrm{i}}=$ az adatsor "i" eleme

$E \min =$ az adatsor legkisebb eleme

$E \max =$ az adatsor legnagyobb eleme

Az egyes kémiai összetevők koncentrációja és a vízminta mikrobiológiai terhelése közötti összefüggést korreláció analízissel vizsgáltuk. A vizsgálat során a mért adatokkal dolgoztunk, azok normalizálása nélkül. 


\section{Eredmények és értékelésük}

\subsection{Mikrobiológiai vizsgálatok}

A vizsgált időszakban a Pannon-Víz Zrt. múködési területén 2980 hálózati ivóvíz mintavétel történt mikrobiológiai vizsgálat céljára. Ebből 289 minta volt kifogásolt, mely minták 90 településről származtak. A pozitív minták mindegyike kizárólag mikrobiológiai szempontból volt kifogásolt, esetenként több paraméter tekintetében is, viszont a kémiai vízminőségi jellemzők mindegyike a határérték illetve a parametrikus érték alatt volt.

A vizsgált mikrobiológiai paraméterek közül a coliform baktériumok szempontjából találtuk a legtöbb kifogásolt mintát: 264 mintában, a kifogásolt minták 91\%-ában volt kimutatható (1. ábra). A coliform baktériumcsoport igen jó szennyezettség jelző paraméter az ide tartozó fajok változatos életstratégiája miatt. Ezt követte a $22^{\circ} \mathrm{C}$-os telepszám: 162 mintában, a kifogásolt minták 56\%-ában mutattuk ki. A $37^{\circ} \mathrm{C}$-os telepszám miatti kifogásoltság már jóval kevesebb volt (39 minta, a kifogásolt minták 13,5\%a), ugyanis az ivóvízhálózatban lévő körülmények elsősorban a $22^{\circ} \mathrm{C}$-os telepszámba tartozó hidegkedvelő baktériumcsoportok szaporodása számára nyújtanak ideális körülményeket. Az Enterococcus baktériumok 21 mintában voltak jelen. Mivel termofil baktériumok, ezért az ivóvízhálózatban lévő körülmények kevésbé kedveznek számukra. A Pseudomonas aeruginosa életstratégiáját tekintve könnyen elszaporodhat a vízhálózatokban és a víztisztítási technológiai pontokon, ennek ellenére csak 20 mintában tudtuk kimutatni. Az Escherichia coli szempontjából kifogásolt minták száma 18. A vizsgált időszakban a 2980 mintából egy alkalommal sem tudtuk az anaerob Clostridium perfringens kórokozót kimutatni. Ez egy termofil baktérium, amelynek nem kedvez a vízhálózati környezet.

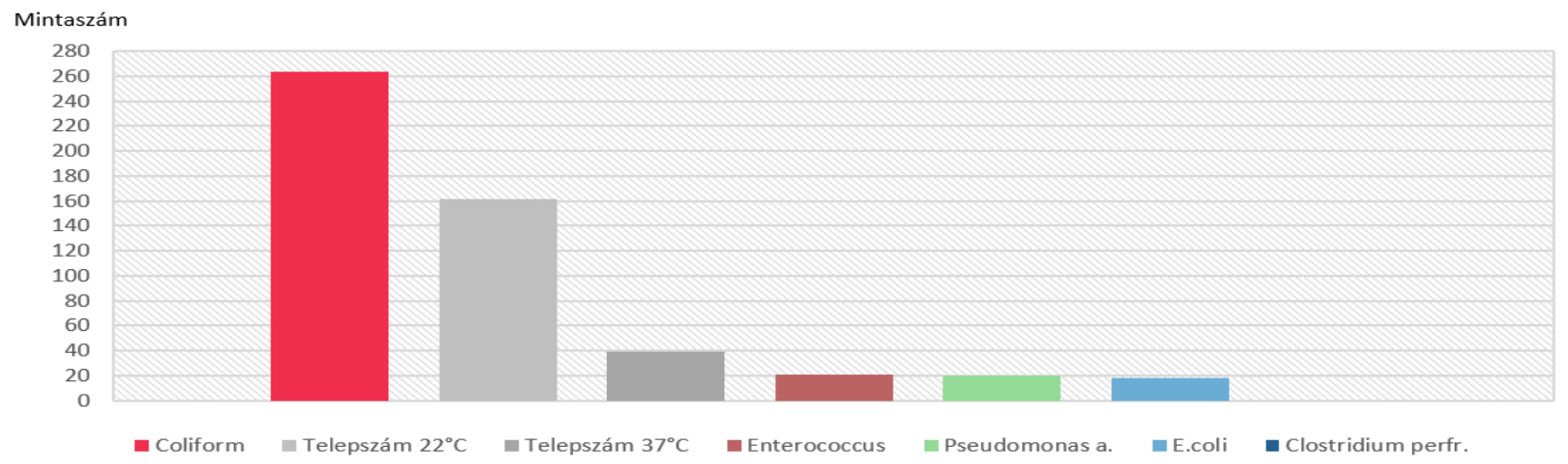

1. ábra: A 2015. január - 2017. október között mért határérték feletti mikrobiológiai jellemzők eloszlása.

\subsection{A pozitív minták szezonális változásának nyomon követése}

A vizsgált időszakban a mikrobiológiai pozitív minták vízhőmérséklete az évszakoknak megfelelően szezonálisan változott (2. ábra). A leghidegebb minták hőmérséklete nem csökkent $5,9^{\circ} \mathrm{C}$ alá, míg a legmelegebb minták nem emelkedtek $22,6^{\circ} \mathrm{C}$ fölé. A vízhálózat hőmérsékletének szezonális változását összevetve az évszakokkal azt tapasztaltuk, hogy a vízhálózat hőmérsékletváltozása késleltetve 
követte az évszakos környezeti hőmérsékletváltozást, hiszen a szeptemberi minták a legmelegebb vízminták közé tartoztak, míg a decemberi mintákra az átmeneti vízhőmérséklet volt jellemző.

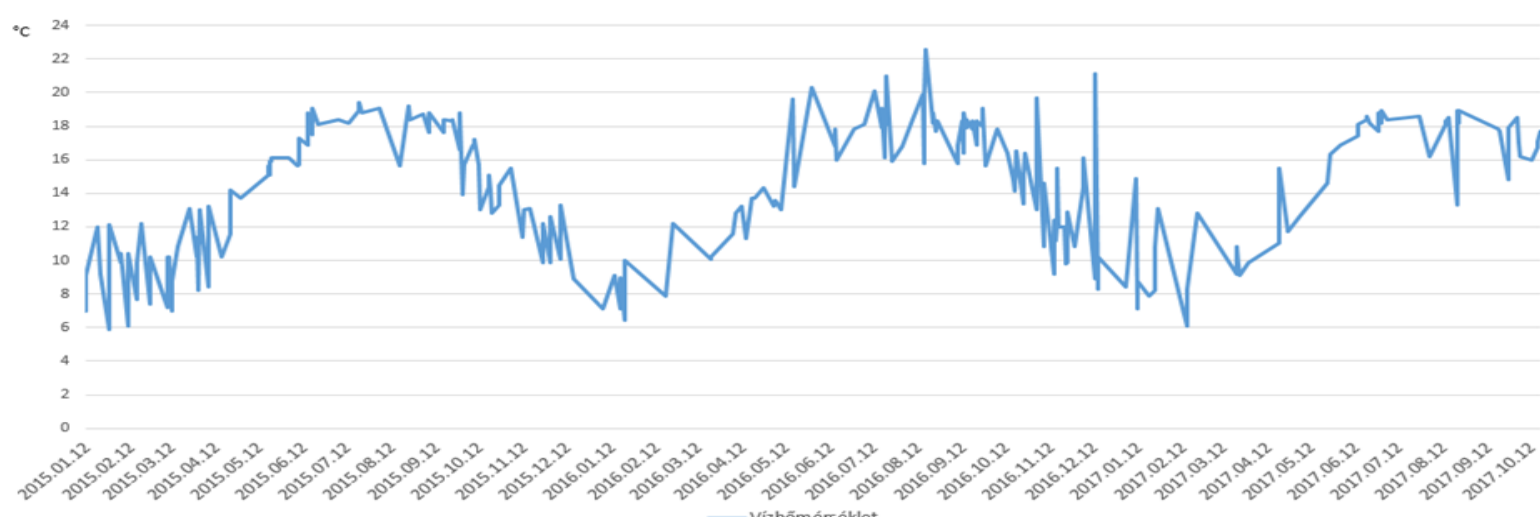

2. ábra: A mikrobiológiailag pozitív minták vízhőmérsékletének változása 2015. január - 2017. október között.

Az Escherichia coli és Enterococcus baktériumok csíraszámának alakulásában szezonális változás volt nyomon követhető (3. ábra). A $17^{\circ} \mathrm{C}$ alatti mintákban az Escherichia coli-Enterococcus aránya 4:11 volt, míg a $17^{\circ} \mathrm{C}$ feletti minták esetén 13:9. Láthatjuk, hogy a meleg időszakban vett minták csíraszáma jellemzően magasabb, ahol az Enterococcus csíraszám elérte a 80-110/100 ml koncentrációt, az Escherichia coli pedig a 150/100 ml koncentrációt is. Ezek a baktériumok termofil, melegkedvelő bélbaktériumok, a meleg környezetet kedvelik, ezért a felmelegedett víz kedvezett az elszaporodásuknak. A hideg időszakban gyűjtött pozitív mintákban az Escherichia coli és Enterococcus telepszám nem volt jellemző, vagy alacsony csírszámban jelentek meg.

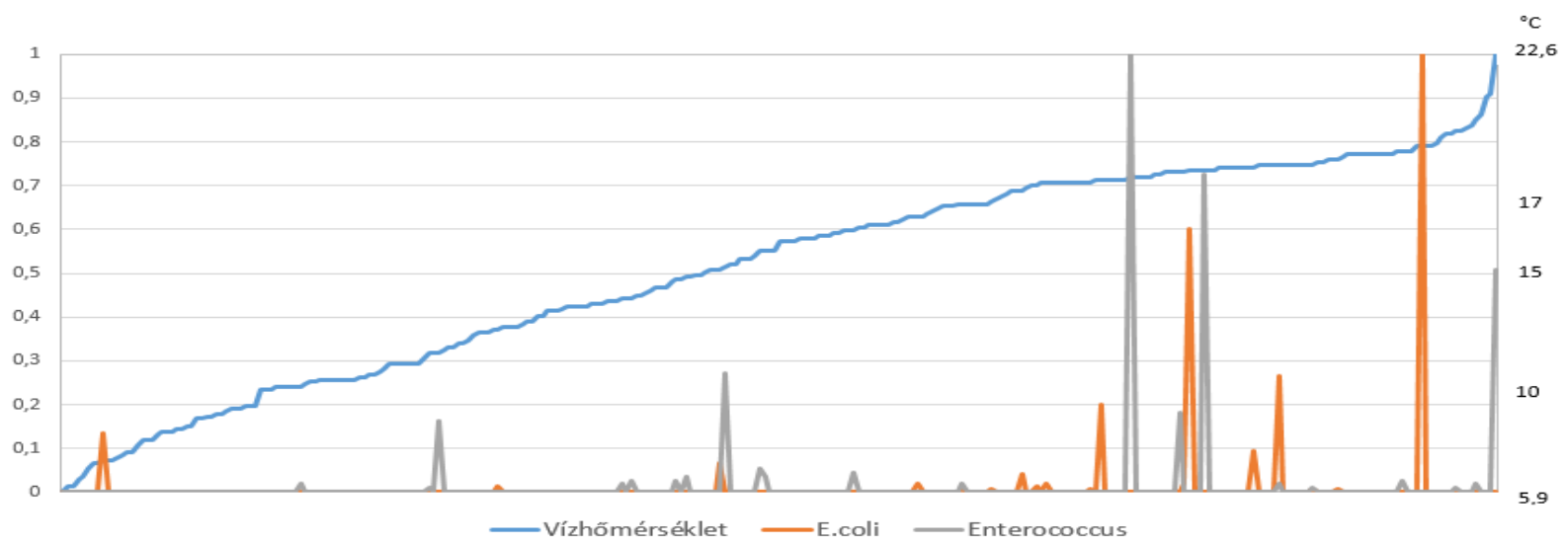

3. ábra: A pozitív minták Escherichia coli és Enterococcus telepszám változása a vízhőmérséklet függvényében a csíraszámok normál értékeivel feltüntetve.

A Pseudomonas aeruginosa esetében szintén azt tapasztaltuk, hogy a hálózati vízhőmérséklet emelkedésével megnőtt a pozitív minták csíraszáma. $17^{\circ} \mathrm{C}$ alatt 10 mintából volt kimutatható a Pseudomonas aeruginosa, a legmagasabb csíraszám 10/100 ml volt. A meleg időszakban vett mintákból 11 esetben került meghatározásra a baktérium, azonban a legmagasabb csíraszám 60/100 $\mathrm{ml}$ volt (4. ábra). Tehát a Pseudomonas aeruginosa szezonális megjelenése szintén kimutatható volt a vizsgált időszakban. 


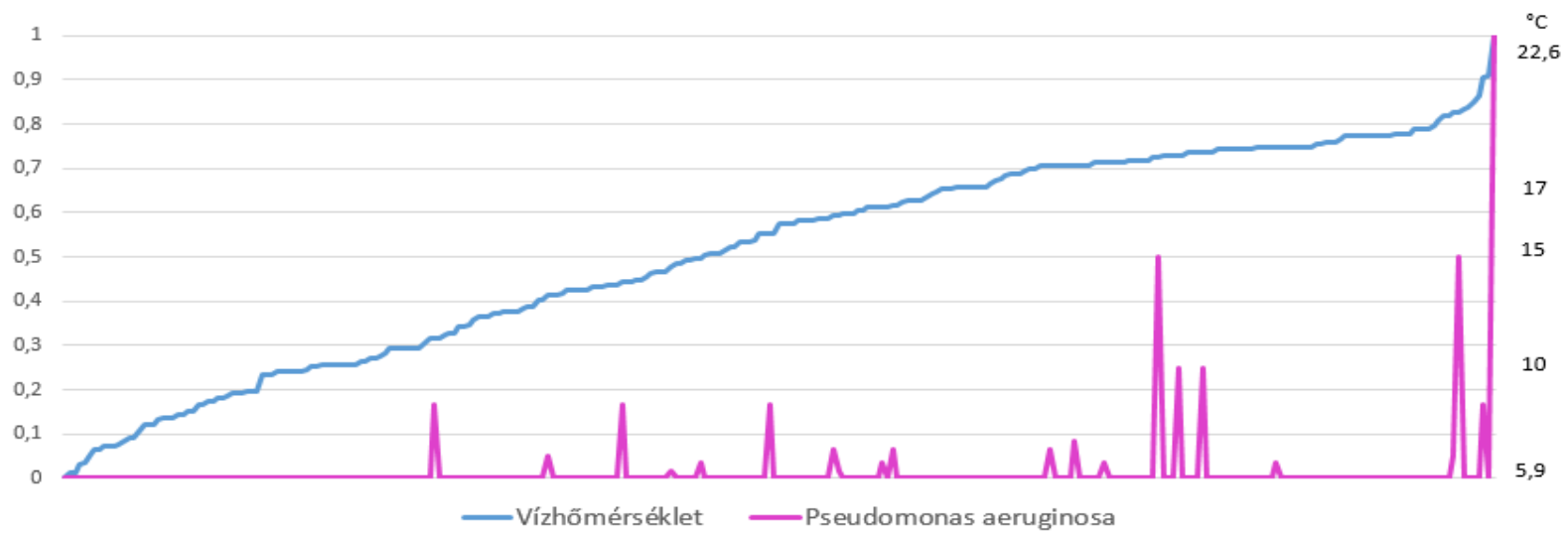

4. ábra: A pozitív minták Pseudomonas aeruginosa telepszám változása a vízhőmérséklet függvényében a csíraszámok normál értékeivel feltüntetve.

A coliform baktériumok szezonális eloszlását az előzőekkel ellentétben nem tapasztaltuk. Ez a paraméter a pozitív minták 91\%-ában volt jelen. A coliformok elszaporodása minden vízhőmérséklet esetén jellemző volt. Ennek oka az lehetett, hogy a coliform baktériumok köre sokféle baktériumot magába foglaló csoport (pl. Citrobacter, Enterobacter, Klebsiella), melyek változatos életstratégiával jellemezhetők, így hőtűrőképességük is nagy, ezért a hideg és meleg vizekben egyaránt könnyen elszaporodnak (5. ábra). A legmagasabb csíraszám sok esetben elérte a 150-300/100 ml koncentrációt.

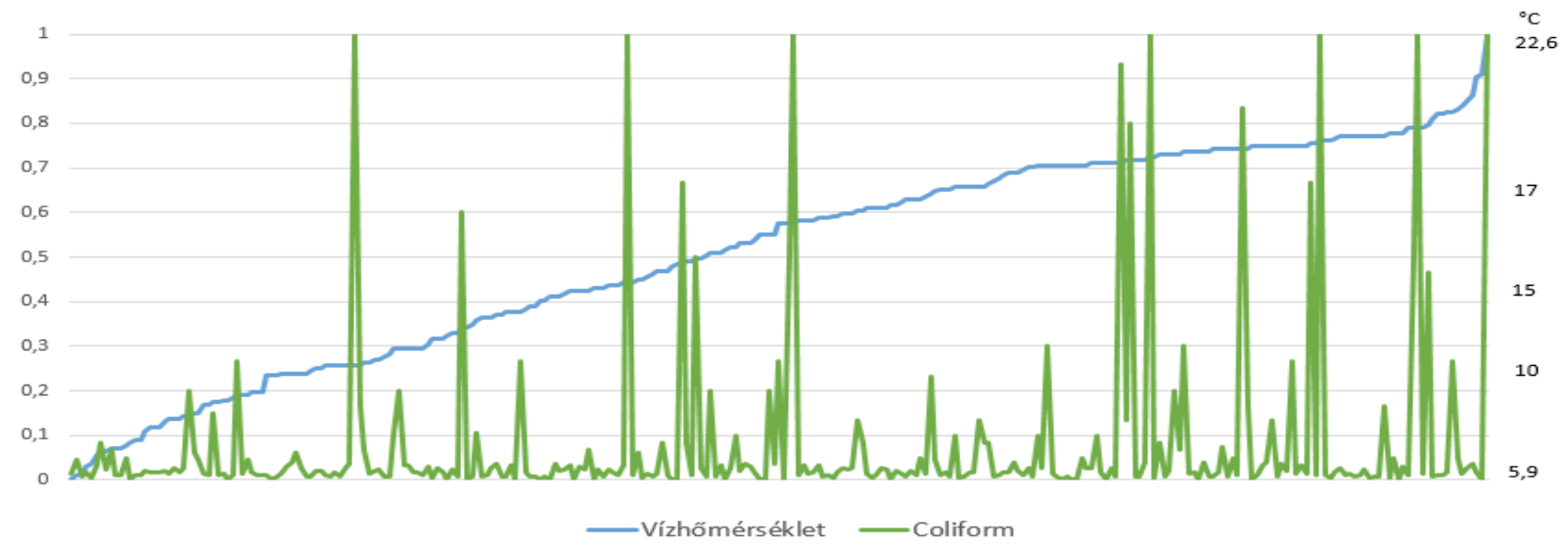

5. ábra: A pozitív minták coliform telepszám változása a vízhőmérséklet függvényében a csíraszámok normál értékeivel feltüntetve.

Az összcsíraszám egy szintén tágabb baktériumcsoportot jelent, amelybe az oligotróf, azaz kis szervesanyag igényű pszichrofil és mezofil baktériumok tartoztak. Az összcsíraszám esetében határérték feletti koncentrációt mind a hideg, mind a meleg időszakban vett mintákban egyaránt hasonló eloszlásban mértünk (6. ábra), így szezonális dinamikát ez esetben sem tudtunk kimutatni. Érdekes azonban, hogy a $15-17^{\circ} \mathrm{C}$ közötti mintákban a $22^{\circ} \mathrm{C}$-os és $37^{\circ} \mathrm{C}$-os telepszámot nem vagy csak viszonylag alacsony csíraszámban tudtunk mérni, míg a $15^{\circ} \mathrm{C}$ alatti és a $17^{\circ} \mathrm{C}$ feletti mintákban az összcsíraszám magas, sok esetben kiugróan magas volt. 


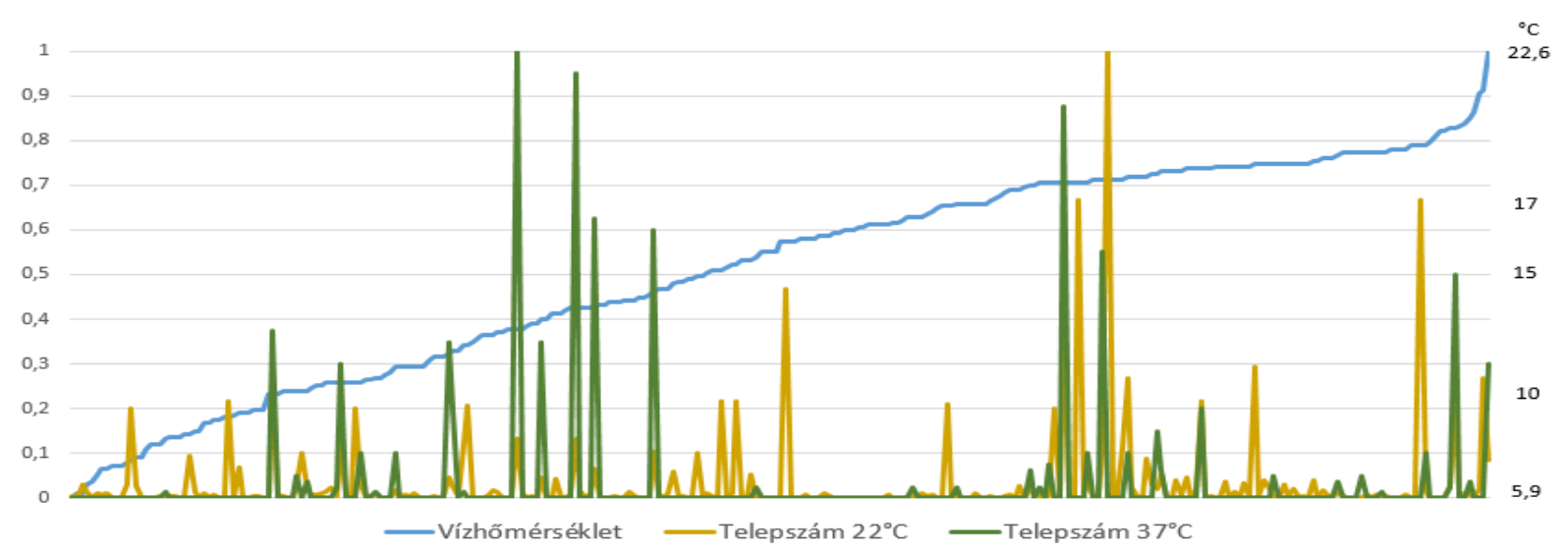

6. ábra: $A 22^{\circ} \mathrm{C}$-os és $37^{\circ} \mathrm{C}$-os telepszám eloszlása a vízhőmérséklet függvényében.

\subsection{A kémiai és a mikrobiológiai jellemzők közötti összefüggések keresése}

A vizsgálatok során a vízminták kémiai analízisére is sor került, azonban nem minden alkalommal és nem minden kémiai paraméter mérése történt meg. A 2015. január és 2017. október közötti időszak mikrobiológiailag negatív hálózati ivóvízmintáiban a vizsgált kémiai paraméterek határérték alatt maradtak.

A 289 mikrobiológiai pozitív minta közül 130 minta ammónium-tartalmát vizsgáltuk meg az elemzett időszakban. A 201/2001. kormányrendelet alapján az ammóniumra, mint indikátor vízminőségi paraméterre vonatkozó parametrikus érték $0,5 \mathrm{mg} / \mathrm{l}$, amely értéket a mért adatok nem is közelítik. 108 mintában 0,01 mg/l koncentrációt mértünk, a legmagasabb mért érték 0,2 mg/l volt. Négy esetben mértünk az átlagos értékhez viszonyítva kiugró értéket 0,07 mg/l; 0,09 mg/l; 0,16 mg/l; 0,2 mg/l koncentrációval. A 0,07 mg/l, illetve 0,09 mg/l ammónium-koncentrációjú minták esetében a coliformcsíraszám határérték feletti volt (15/100 ml; 40/100 ml). A 0,16 mg/l koncentrációjú minta coliformcsíraszáma 1/100 ml, Pseudomonas aeruginosa csíraszáma 30/100 ml volt, míg a 0,2mg/l ammóniumkoncentrációjú minta mikrobiológiai pozitivitását 4/100 ml coliform-csíraszám okozta.

A nitritiont (határértéke 0,5 mg/l) egy vízmintából sem tudtunk kimutatni a vizsgált időszakban.

A minták nitrát-koncentrációja 0-7,9 mg/l közötti értéket vett fel, azaz nem is közelíti a 201/2001. kormányrendeletben megszabott $50 \mathrm{mg} / \mathrm{l}$ határértéket. Három mintából a többihez képest kiugróan magas koncentrációban tudtunk nitrátot kimutatni. A 16,4 mg/l és a 19,5 mg/l nitrát-koncentrációjú mintát 4/100 ml, illetve $70 / 100 \mathrm{ml}$ coliform csíraszám jellemezte. A $21 \mathrm{mg} / \mathrm{l}$ nitrát-koncentrációt alacsony (1/100 ml) Pseudomonas aeruginosa csíraszám mellett mértük.

A KOIps értékét 130 mintában vizsgáltuk a mikrobiológiailag pozitív minták közül. A mért értékek között jelentős eltérést nem tudtunk kimutatni. 75 mintában 0,2-0,28 mg/l O $\mathrm{O}_{2}$ között, 55 mintában 0,3$1,58 \mathrm{mg} / \mathrm{l} \mathrm{O}_{2}$ közötti értékeket mértük. Az alacsony KOIps értékek leggyakrabban határértéket meghaladó coliform csíraszám (1-300/100 ml) és $22^{\circ} \mathrm{C}$-os telepszám (630-650/1 ml) mellett jelentek meg. A legmagasabb értékű $\left(1,44 \mathrm{mg} / \mathrm{l} \mathrm{O}_{2} ; 1,52 \mathrm{mg} / \mathrm{l} \mathrm{O}_{2}, 1,58 \mathrm{mg} / \mathrm{l} \mathrm{O}_{2}\right)$ mintákból coliform baktériumtelepeket (25-80/100 ml) lehetett kitenyészteni. 
A mikrobiológiai paraméterek és a kémiai paraméterek közötti lineáris kapcsolatot korreláció analízissel vizsgáltuk. A korrelációs koefficiensek értéke azonban nem jelez összefüggést a kémiai és mikrobiológiai paraméterek között (2. táblázat).

\begin{tabular}{|l|l|l|l|}
\hline & \multicolumn{1}{|c|}{ Ammónium } & \multicolumn{1}{|c|}{ Nitrát } & \multicolumn{1}{c|}{ KOIps } \\
\hline Telepszám $22^{\circ} \mathrm{C}$ & $-0,01762$ & $-0,01086$ & 0,02033 \\
\hline Telepszám $37^{\circ} \mathrm{C}$ & $-0,10759$ & $-0,053$ & $-0,16142$ \\
\hline Coliform baktériumok & $-0,07683$ & 0,01772 & $-0,02222$ \\
\hline Escherichia coli & $-0,06567$ & $-0,02122$ & 0,18689 \\
\hline Enterococcus baktériumok & $-0,08494$ & $-0,07562$ & $-0,00135$ \\
\hline Pseudomonas aeruginosa & 0,17848 & $-0,07307$ & $-0,09832$ \\
\hline
\end{tabular}

2. táblázat: Az egyes mikrobiológiai paraméterek és az ammónium, nitrát, KOIps közötti korrelációs koefficiensek.

Nem találtunk összefüggést az egyes kémiai paraméterek között sem. A permanganátos kémiai oxigénigény és a nitrát korrelációs együtthatója -0,13157, az ammónium és a permanganátos kémiai oxigénigényé -0,08461. Az ammónium és a nitrát korrelációs együtthatója -0,04513.

Felföldi et al. a Pseudomonas aeruginosa és Legionella fajok települési ivóvízhálózatokban történt vizsgálatuk során meghatározták a vízminták kémiai és mikrobiológiai jellemzőit. Az ő kutatásaik alapján sem volt kimutatható a korreláció a vízminták kémiai és mikrobiológiai paraméterei között. Azt feltételezik, hogy a fizikai-kémiai paraméterekkel szemben a patogének jelenlétére inkább a mikroba közösség összetétele, a nem patogén és patogén mikroorganizmusok közötti kölcsönhatások (mint pl. versengés) és a csőhálózat belső felszínén kialakult biofilm réteg struktúrája van hatással [13].

\section{Következtetések}

A mérési eredmények feldolgozása és elemzése után az alábbi következtetéseket vontuk le. A szezonális változás tekintetében megfigyeltük, hogy a legmelegebb minták $\left(17-22,6^{\circ} \mathrm{C}\right)$ a júniusszeptember, a leghidegebbek $\left(5,9-10^{\circ} \mathrm{C}\right)$ a január-március, az átmenetiek $\left(10-17^{\circ} \mathrm{C}\right)$ az április-május, illetve az október-november-december időszakokban kerültek mintázásra, azaz a vízhálózat hőmérsékletváltozása késleltetve követte az évszakos környezeti hőmérsékletváltozást.

A pozitív minták szezonális változásait elsősorban az Escherichia coli és Enterococcus baktérium szennyezettség alapján tudtuk kimutatni. A melegebb, $17-22^{\circ} \mathrm{C}$ hőmérsékletű vizekben a fekál indikátor Escherichia coli és Enterococcus baktériumok megjelenése gyakoribb volt, és a vízmintákban a csíraszám is lényegesen magasabb volt, mint a hidegebb időszakban vett minták esetén. Az Enterococcus csíraszám elérte a 80-110/100ml koncentrációt, az Escherichia coli pedig a 150300/100ml koncentrációt is. Ezek az eredmények nem meglepőek, hiszen az Escherichia coli és Enterococcus bélbaktériumok igen érzékenyek a környezeti hőmérsékletre. Elszaporodásuknak kizárólag a felmelegedett vízhőmérséklet kedvez, míg a hideg vizekben nehezen, vagy egyátalán nem szaporodnak.

A szezonális változás a Pseudomonas aeruginosa eredményekben is tükröződött. Hasonlóan az Escherichia coli és Enterococcus csíraszámának eloszlásához, a Pseudomonas is elsősorban a melegebb 
vizekben volt jellemző, bár a hőmérsékleti elkülönülés nem volt olyan mértékű, mint a fekál indikátorok esetében. A $17-22^{\circ} \mathrm{C}$ közötti vizekben a Pseudomonas csíraszáma elérte a 60/100ml koncentrációt is, míg a hidegebb mintákban a Pseudomonas koncentráció 0-5 csíraszám volt 100 mlben.

A coliform és telepszám tekintetében nem volt kimutatható szezonális dinamika. A coliformok a vizsgált időszakban minden évszakban azonos gyakorisággal fordultak elő, és a mintákban a baktérium-koncentráció sem mutatott évszakos különbséget. A legmagasabb coliform-számot $(300 / 100 \mathrm{ml}) 10,2^{\circ} \mathrm{C}, 15,5^{\circ} \mathrm{C}, 18,6^{\circ} \mathrm{C}, 19,1^{\circ} \mathrm{C}$ mellett egyaránt ki lehetett mutatni. Szezonális változást a $22^{\circ} \mathrm{C}$-os és $37^{\circ} \mathrm{C}$-os telepszám esetében sem tudtunk kimutatni, azonban a $15-17^{\circ} \mathrm{C}$ közötti mintákban a csíraszám alacsony, míg a $15^{\circ} \mathrm{C}$ alatti, és $17^{\circ} \mathrm{C}$ feletti mintákban az összcsíraszám magas, sok esetben kiugróan magas volt (2000-3000/1 ml). Ez az eredmény várható volt, hiszen mindkét baktériumcsoport több különböző taxont foglal magába, melyek hőtűrőképessége különböző lehet.

A vizsgált időszakban a 289 mikrobiológiai szempontból pozitív minta egyikében sem mértünk határérték feletti vagy akár közeli kémiai paramétereket. A mikrobiológiai és kémiai paraméterek között a korreláció analízis alapján nem mutatható ki összefüggés.

\section{Hivatkozások}

[1] N. J. Ashbolt (2015) Microbial Contamination of Drinking Water and Human Health from Community Water Systems. Current Environmental Health Reports, 2(1), 95-106.

[2] J. Wingender - H.C. Flemming (2011) Biofilms in drinking water and their role as reservoir for pathogens. International Journal of Hygiene and Environmental Health, Vol. 214(6), 417-423.

[3] K.E. Fish - A.M. Osborn - J. Boxall (2016) Characterising and understanding the impact of microbial biofilms and the extracellular polymeric substance (EPS) matrix in drinking water distribution systems. Environmental Science: Water Research and Technology, Vol. 2, 614-630.

[4] S. Husband - K.E. Fish - I. Douterelo - J. Boxall (2016) Linking discolouration modelling and biofilm behaviour within drinking water distribution systems. Water Science and Technology: Water Supply, Vol. 16(4), 942-950.

[5] I. Bíró - R. Gerencsérné Berta - E. Barabás - I. Galambos (2017) Biofilmek jelenléte az ivóvízelosztó hálózatokban. MASZESZ Hírcsatorna, 2017/6., 52-67.

[6] I. Douterelo - S. Husband - V. Loza - J. Boxall (2016) Dynamics of Biofilm Regrowth in Drinking Water Distribution Systems. Applied and Environmental Microbiology, Vol. 82(14), 4155-4168.

[7] BMGE Vízi Közmű és Környezetmérnöki Tanszék, Víztisztítás, BMGE Vízi Közmű és Környezetmérnöki Tanszék, 2007

[8] S. Chowdhury (2012) Heterotrophic bacteria in drinking water distribution system: a review. Environmental Monitoring and Assessment, Vol. 184(10), 6087-6137.

[9] P. Slaats - L. Rosenthal - W. Siegers (2004) Processes involved in the generation of discolored water (Awwarf Report Series). American Water Works Association Research Foundation/KIWA.

[10] P.S. Husband - J.B. Boxall (2011) Asset deterioration and discolouration in water distribution systems. Water Research Vol. 45, 113-124. 
[11] I. Douterelo - R.L. Sharpe - J.B. Boxall (2013) Influence of hydraulic regimes on bacterial community structure and composition in an experimental drinking water distribution system. Water Research Vol. 47, 503-516.

[12] Z. G. Homonnay - Gy. Török - K. Márialigeti - E.M. Tóth (2009) Térbeli és időbeli változások a fővárosi ivóvízhálózat baktériumközösségében. 8. Magyar Ökológus Kongresszus Kiadványa, 86.

[13] T. Felföldi - T. Tarnóczai - Z.G. Homonnay (2010) Presence of potential bacterial pathogens in a municipal drinking water supply system. Acta Microbiologica et Immunologica Hungarica, Vol. 57, 165-179.

A publikáció anyagának a 2018. okt. 11-12-én zajló Környezetmérnöki Konferencia és Szakmai Napon történő bemutatása az EFOP-3.5.1-16-2017-00013 pályázat keretében valósulhatott meg. 